\title{
Strengthening Spiritual Practices among Community: Dhikr Activities in Negeri Sembilan, Malaysia
}

\author{
Mohammad Fahmi Abdul Hamid ${ }^{*}$, Khairul Azhar Meerangani' ${ }^{2}$, Ishak Suliaman ${ }^{3}$, Mohd Farhan \\ Md Ariffin ${ }^{4}$, Amran Abdul Halim ${ }^{5}$
}

1 Academy of Contemporary Islamic Studies, Universiti Teknologi MARA, Malaysia; e-mail: fahmihamid@uitm.edu.my

2 Academy of Contemporary Islamic Studies, Universiti Teknologi MARA, Malaysia; e-mail: azharmeerangani@uitm.edu.my

3 Academy of Islamic Studies University of Malaya, Malaysia; e-mail: ishakhs@um.edu.my

4 Research Centre for Quran and Sunnah, Universiti Kebangsaan Malaysia, Malaysia; e-mail: farhan.ariffin@ukm.edu.my

5 Faculty of Quranic and Sunnah Studies, Universiti Sains Islam Malaysia, Malaysia; e-mail: amranabdulhalim@usim.edu.my

* Correspondence

Received: 2021-03-08; Accepted: 2021-07-25; Published: 2021-08-21

\begin{abstract}
Tarekat tasawuf, the Sufi orders, has been established in Negeri Sembilan since 1900 and began to strengthen its existence in spiritual activities such as the implementation of dhikr tarekat tasawuf activities among the local community. This article will highlight the impact of implementing the dhikr activities of tarekat tasawuf, which is practiced periodically to strengthened the spirituality of the community in Negeri Sembilan. This research employs a qualitative approach that involved library studies, reviewing relevant documents, and conducting interviews with the Registrar of Tarekat Tasawuf Division of the Negeri Sembilan, Mufti Department, and the Sheikh of the tarekat involved. In Negeri Sembilan, Malaysia 13 Sufi practice centres conduct regular dhikr activities that impact the community. The existence of tarekat practice centres in Negeri Sembilan has been plotted to see the distribution and centralisation of tarekat centres. In addition, the form of $d h i k r$ practiced in the dhikr ceremony is also explained through a simple framework. The results also showed that the Seremban district is the highest area in Malaysia that has tarekat practice centres. Indirectly, the dhikr activities of tarekat tasawuf have provided space for the local community to engage in more systematic spiritual activities. The efforts implemented by the Sufi tarekat practice centre in Negeri Sembilan are expected to be used as an example by other states in Malaysia so that the community is more interested in the Sufi tarekat dhikr ceremony.
\end{abstract}

Keywords: Impact; Tarekat Tasawuf; Dhikr Activities; Spirituality; Negeri Sembilan.

Abstrak: Tarekat tasawuf sebagai kelompok sufi telah berdiri di Negeri Sembilan sejak tahun 1900 dan mulai memantapkan eksistensinya dalam kegiatan spiritual seperti pelaksanaan kegiatan dzikir tarekat tasawuf di kalangan masyarakat setempat. Artikel ini akan menyoroti dampak dari pelaksanaan kegiatan dzikir tasawuf tarekat yang dilaksanakan secara berkala untuk memperkuat spiritualitas masyarakat di Negeri Sembilan. Penelitian ini menggunakan pendekatan kualitatif yang melibatkan studi kepustakaan, menelaah dokumen yang relevan, dan melakukan wawancara dengan pihak penanggungjawab tarekat tasawuf Negeri Sembilan, dan Syekh tarekat yang terlibat. Di Negeri Sembilan, Malaysia terdapat 13 pusat latihan sufi yang melakukan kegiatan dzikir secara rutin dan memberikan dampak pada masyarakat. Keberadaan pusat-pusat tarekat di Negeri Sembilan telah diplot untuk melihat sebaran dan sentralisasi pusat-pusat tarekat. Selain itu, bentuk dzikir yang dipraktikkan dalam upacara dzikir juga dijelaskan melalui kerangka sederhana. Hasil penelitian menunjukkan bahwa Kabupaten Seremban merupakan daerah tertinggi di Malaysia yang memiliki 
balai latihan tarekat. Secara tidak langsung, kegiatan dzikir tasawuf tarekat telah memberikan ruang bagi masyarakat setempat untuk melakukan kegiatan spiritual yang lebih sistematis. Upaya yang dilakukan oleh pusat latihan tarekat sufi di Negeri Sembilan ini diharapkan dapat dijadikan contoh oleh negara-negara lain di Malaysia agar masyarakat lebih tertarik dengan upacara dzikir tarekat sufi.

Kata Kunci: Dampak; Kegiatan Dzikir; Negara Sembilan; Spiritualitas; Tarekat Sufisme.

\section{Introduction}

Sufism is demanded in Islam because its practice can cleanse the soul, form praiseworthy morals and remove abominable traits (Salleh et al., 2020). One way to practice it is through tarekat (tariqah) activities. Tarekat tasawuf is a systematic organisation that has importance to Muslims, and the best tarekat is based on al-Quran and al-Sunnah. Based on historical highlights, Negeri Sembilan is one of the earliest states in Malaysia that received the Sufi's da'wa's initiated by local preachers. This tarekat tasawuf (a sufi order) was first introduced and brought into Negeri Sembilan in the early 1900s through the Tarekat Naqsyabandiyah, followed in 1902 by the Tarekat Ahmadiyah al-Dandarawiyyah (Ibrāhim, 1996). However, there was still no authority to monitor the course of Sufism in Negeri Sembilan at that time. Written documents related to the degree of permission to practice and disseminate tarekat tasawuf and documents related to the practice of tarekat have not been updated and stored in a systematic database. All related documents are only kept as a collection of sheikh tarekat in the form of manuscripts (Fahmi \& Ishak, 2017). This results in the existence of irresponsible parties, that manipulating and disguising behind the name of the tarekat tasawuf by spreading propaganda that is contrary to the basic principles of the tarekat tasawuf itself. This incident confuses the people so that they find it difficult to distinguish the authenticity of Sufism.

In the beginning, the tarekat tasawuf dhikr ceremony activities were only focused on the two tarekat, and the acceptance among the community was still at a moderate level. However, now, the institution of tarekat tasawuf in Negeri Sembilan is showing its significant development as a result of initiatives and strong support from the authorities, especially the Negeri Sembilan Mufti Department (Kamal, 2017). This study uses a qualitative and descriptive approach that uses document analysis methods, observation, and interviews to obtain research data. The research analysing documents such as articles related to the history of the entry of the tarekat and tarekat tasawuf registration documents obtained from the Tarekat Tasawuf Division of the Negeri Sembilan Government Mufti Department were also used in this study. Next, through the results of the data on the number of Sufi practice centres, a plot of the distribution of tarekat practice centres according to districts in Negeri Sembilan was created.

The form of dhikr practiced in the dhikr ceremony at the Tarekat Tasawuf Practice Centre in Negeri Sembilan is also explained through a simple framework. The form of dhikr practice was obtained in this study through observation in five tarekat practice centres involved in Negeri Sembilan. According to Idris Awang (2001), observation is the process of observation and recording by researchers on systematically studied phenomena. Sabitha (2005) explained that the observation process is a way of collecting data without involving communication and asking the respondents. The observation process can be considered an important method in qualitative research because it is a direct observation process (Lebar, 2009). This is in line with Sabitha (Marican, 2005) who argues that the process of data collection through observational studies is more accurate because it is less influenced by memory factors. This is because the data recorded is the behaviour observed during the observation. The process of recording and observations can be implemented by using video recorders, checklists, and other tools (Piaw, 2012).

In this study, two tools were used namely checklist and video recorder tool. The observation process was done three times in December 2017 to see the consistency of the practice of dhikr in the practice centre of the tarekat. Observation sessions were conducted by the researcher himself to obtain the main source for data collection. All the conditions of consent set by the Sufi practice centre were complied with during the observation process. The transfer of dhikr practice data in dhikr ceremonies obtained through the observation process at the practice centre is translated into descriptive writing. 
In addition, an interview with Ustaz Syaiful Nizam Md Jan, the Assistant Mufti of the Sufi Order Division of the Negeri Sembilan Government Mufti Department, was conducted to obtain data to support the findings of this study. The interview method was used to seek information to confirm the information obtained during the observation process. Mok Soon Seng (2009) explained that the interview method is a process of obtaining research data and information directly from authoritative individuals through faceto-face meetings. Semi-structured interviews were used to obtain data because the researcher was free to question and find out in more depth the respondents 'answers based on a formal question that had been asked (Piaw, 2012). Finally, the data that have been gathered are analysed related to the impact of the implementation of $d h i k r$ ceremonies at the Sufi training centre on the spiritual practice of the community in Negeri Sembilan.

\section{History of the Entry of Sufism to Negeri Sembilan}

In general, there are nine sects of tarekat tasawuf that play an important role in this archipelago, namely Tarekat Qadiriyah, Naqsyabandiyah, Rifaiyah, Syadhiliyah, Chistiyah, Syattariyah, Ahmadiyah, Tijaniyah and Alawiyah (Al-Attas, 1963). However, in Malaysia itself, there are fifteen sects that have been found, namely Tarekat Naqsyabandiyah, Ahmadiyah, Qadiriyah, Qadiriyah Naqsyabandiyah, Syatiriyyah, Alawiyah, Shammaniyah, Aiderusiyah, Mufradiyah, Suhrawardiyah, Rifa'iyah, Darqawiyah, Khalwatiyah, Shadhiliyah and Sanusiyah (Hassan, 1990). The early date of the entry of the tarekat tasawuf into Negeri Sembilan could not be ascertained accurately because there were no official documents about it. However, based on some historians, the earliest date of entry of tarekat tasawuf into Negeri Sembilan was around 1900-1902 through Tarekat Ahmadiyyah al-Dandarawiyyah. This view is based on the reception of degree by the principal founder of this sect in Negeri Sembilan in that year from the sect's founder, Sheikh Muhammad bin Ahmad al-Dandarawi. At the same time, Tarekat Naqsyabandiyyah was also detected entering Negeri Sembilan in the same year through Sheikh Haji Ahmad al-Baqir who opened a surau suluk in the area of Batu 7, Negeri Sembilan.

However, the Ahmadiyyah sect is seen as a more famous sect than the Naqsyabandiyyah because this sect has many followers, apart from the influence of Sheikh Muhammad Sa'id and his son Sheikh Ahmad who is the first mufti of Negeri Sembilan (Meerangani, 2019). However, Sheikh Haji Ahmad alBaqir, who brought the Naqsyabandiyyah sect to Negeri Sembilan, also contributed greatly because he was one of the pioneers of the da'wa of Sufism in Negeri Sembilan (Fahmi \& Ishak, 2017). The spread and development of tarekat tasawuf in Malaysia in general and Negeri Sembilan, in particular, is not as easy as expected. The institution of tarekat tasawuf was once banned by the religious authorities in 1987 (Abdullah, 1997). At that time, the Negeri Sembilan Mufti Department (NSMD) was one of the earliest government bodies to defend this institution to remain established in Malaysia (Danial Farhan, 2016). In this regard, NSMD has taken additional initiatives to uphold the tarekat tasawuf by creating the Negeri Sembilan Tarekat Tasawuf Enactment 2005 (ETTNS). This enactment contains all the policies, rules, and guidelines related to the practice of the tarekat tasawuf. This ensures that the country's implementation of tarekat tasawuf in the country follows the rules and coincides with Islamic law. This enactment was established in 2004 due to discussions between NSMD and the Minister in the Prime Minister's Department, YAB Dato Dr. Abdullah Md Zin recommended that this enactment be carried out first in Negeri Sembilan.

Following that, at the end of 2004, ETTNS was enacted, and the amendment of the Negeri Sembilan Islamic Religious Administration Enactment 2003 was also implemented. A sub-committee was set up to assist the fatwa committee in all matters related to the tarekat tasawuf. The seriousness of NSMD in strengthening the tarekat tasawuf is evidenced by the existence of the Division of Tarekat Tasawuf (DTT) under NSMD in 2007. This division is responsible for implementing ETTNS to organise tarekat tasawuf in Negeri Sembilan more systematically. DTT also acts as an organisation responsible for supervising and monitoring all activities related to tarekat tasawuf in Negeri Sembilan, whether implemented following the provisions of ETTNS or not. The existence of these two essential organisations shows the earnest efforts of the Negeri Sembilan government in preserving the authenticity of the discipline of 
tarekat tasawuf based on al-Quran and al-Sunnah (Syaiful Nizam, Personal Communication, June 14, 2016).

\section{Distribution of the Tarekat Tasawuf Practice Centre in Negeri Sembilan}

Based on the analysis of the relevant documents until 2017, there are 12 sects of tarekat tasawuf found in Negeri Sembilan (Fahmi \& Ishak, 2017). However, there is an increase in one institution of mysticism registered in 2018. The original source of tarekat tasawuf in Negeri Sembilan actually are from the five main sects, namely the Tarekat al-Ahmadiyyah al-Idrisiyyah, Tarekat Naqsyabandiyah, Tarekat Qadariyah wa Naqsyabandiyah, Tarekat Syadhuliyah and Tarekat Dusuqiyah. These five main tarekat later develop into 13 sects of tarekat led by their respective tarekat representatives in Negeri Sembilan. Tarekat al-Ahmadiyyah al-Idrisiyyah in Negeri Sembilan has three sects, namely Tarekat alAhmadiyyah al-Idrisiyyah al-Rashidiah al-Dandarawiah (TAIRD) in Rasah, Tarekat alMuhammadiyyah al-Sanusiyyah al-Idrisiyyah (TMSI) and Tarekat al -Ja'fariyyah al-Ahmadiah alMuhammadiah (TJAM), both in Seremban. Tarekat Naqsyabandiyah Khalidiyyah (TNK) has six sects, namely TNK Kuala Klawang, Lenggeng, Serting Ulu, Felda Bukit Rokan, Jalan Labu Batu 8 Kampung Jawa and Kampung Pantai Batu 7 Seremban. Tarekat Qadariyah and Naqsyabandiyah (TQWN) is conducted in Labu, Seremban, while Tarekat Syadhiliyah (TS) has two sects, namely the Syaziliyah, Rembau and al-Syazuliyah al-Darqawiyah, Bahau. Finally, Tarekat Dusuqiyyah Muhammadiah (TDM) conducted in Seremban. Figure 1 shows the location of the practice centre that has been plotted to see the distribution pattern of tarekat tasawuf in Negeri Sembilan.

\section{Figure 1. Distribution of the Tarekat Tasawuf Practice Centre in Negeri Sembilan}

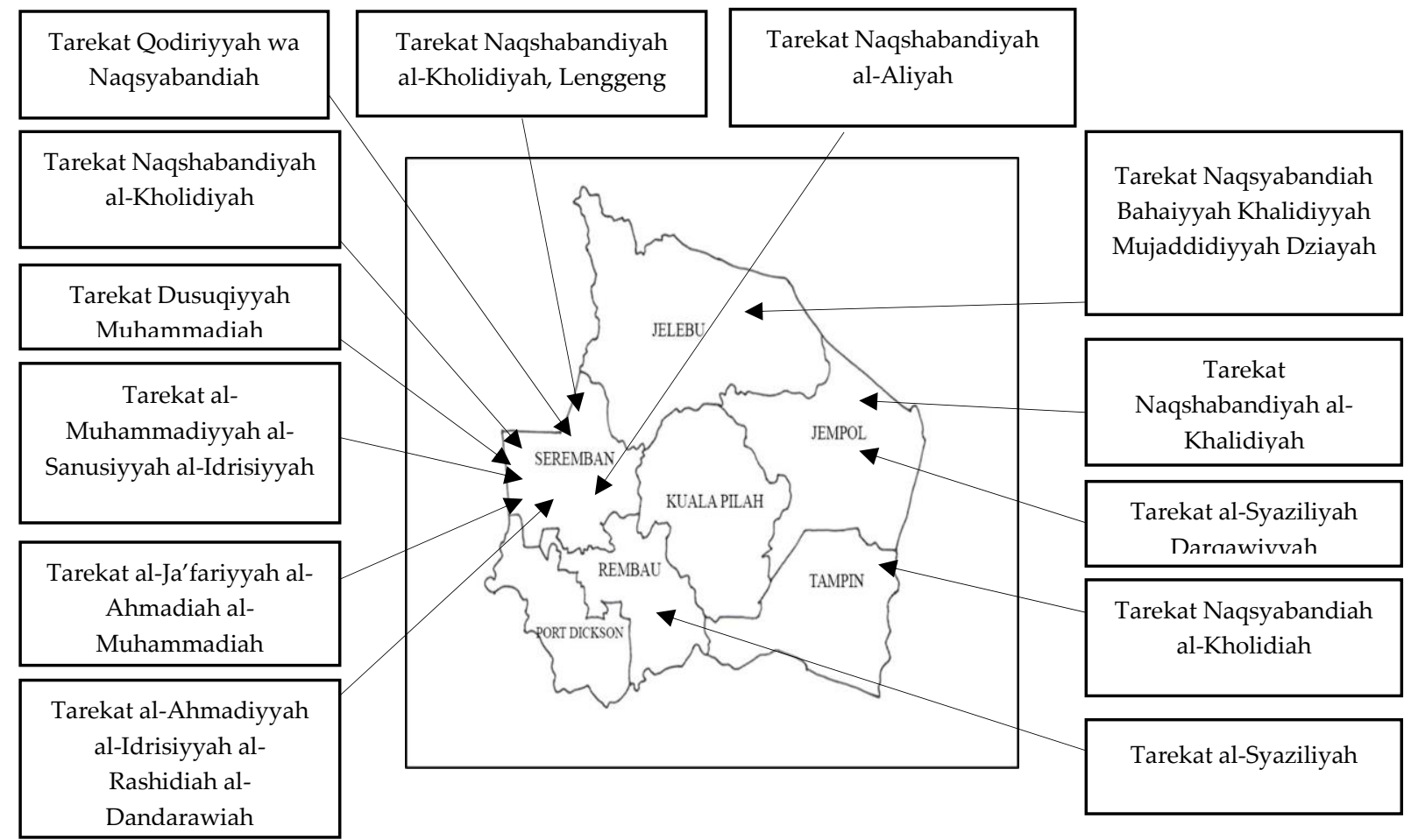

(Source: Researcher Analysis, 2020) 
Based on figure 1, the highest concentration of tarekat practice is around Seremban, with eight practice centres representing $61.5 \%$ of the total number of tarekat practice centres in Negeri Sembilan. The second highest district is Jempol which has two tarekat practice centres, which represent $15.4 \%$. Next, Jelebu, Rembau, and Tampin districts have a tarekat practice centre in each of their respective districts, representing 23.1\%. A total of 13 registered tarekat practice centres in Negeri Sembilan, with five of the seven districts in Negeri Sembilan having tarekat practice centres. The increasing number of registered tarekat in Negeri Sembilan proves that the existence of this tarekat practice centre has succeeded in giving an impact, apart from awareness among the local community, to create spiritualbased studies in their area. The existence of this practice centre serves as a platform for the local community to increase knowledge related to the tarekat tasawuf. Through the existence of many practice centres in Negeri Sembilan, it is hoped to achieve the goal that has been conceived, which is to socialise the tarekat tasawuf to all districts in Negeri Sembilan.

\section{Dhikr Ceremony in the Tarekat Tasawuf in Negeri Sembilan}

In Arabic, the word dhikr comes from the basic word dhakara which means to preserve something, say it with the heart, say it after forgetting and learning (Manzur, 2013). Dhikr can also be interpreted as something spoken orally or presenting something to the heart (Al-Sakandari, 1961). In terms of terminology, dhikr refers to the memory of a human to the God on substance, nature, deeds, law, the Qur'an, prayer, purification, glorification, monotheism, praise, gratitude, glorify Him or ask for His forgiveness (Wizarah al-Awqaf wa al-Shu'un al-Islamiyyah, 1992). Evidence from al-Sunnah that supports the necessity of dhikr in the dhikr ceremony based on the hadith of the Prophet SAW:

Narrated from Abu Hurairah and Abu Sa'eed Al-Khudri, that they bear witness, from the Messenger of Allah, that he said: "There is no group that remembers Allah, except that the angels encompass them, mercy covers them, and tranquillity descends upon them: and Allah remembers (mentions) them before those who are with Him. (Jami' al-Tirmizi, no. Hadith 3378)

According to al-San'ani (2006), this hadith explains the priority of the dhikr ceremony, people who recite dhikr, and the priority of gathering to remember Allah SWT. The dhikr ceremony meant in the hadith is the remembrance ceremony which includes the remembrance of tasbih, takbir (praise for God), and so on, the ceremony of reciting the Qur'an and praying for the good of the world and the hereafter. However, the matter of reading hadith, the council of knowledge, and performing sunnah prayers need to be examined because the dhikr ceremony referred to in the hadith is the dhikr tasbih and takbir ceremony (Al-Asqalani, 2001). In the discipline of tarekat tasawuf, especially in Negeri Sembilan, dhikr is the primary worship in the discipline because it is a spiritual method of a salik, a person who strives towards Allah through the knowledge of tarekat tasawuf to achieve ma'rifatullah (an intuitive knowledge of Allah) (Zahri, 1984). The practice of dhikr in the dhikr ceremony is usually led by a sheikh of tarekat who is a member of tarekat tasawuf. With this practice, tarekat practitioners can recite dhikr in the true sense to get closer to Allah SWT.

Based on figure 2, a brief practical framework of $d h i k r$ in the dhikr ceremony is presented from the five tarekat practice centres, obtained through the observation process. Justification for the selection because these five practice centres have represented the five main tarekat tasawuf. The results of the study found that all tarekat have their practice of dhikr derived from the sheikh of the respective tarekat.

Figure 2 shows, based on observations, that all tarekat in Negeri Sembilan have their practice of dhikr. For TAIRD in Pondok Rasah, Seremban, a weekly dhikr ceremony is held every Thursday night starting after Maghrib prayers. For TNK at Surau Suluk, Kampung Dulang Kuala Klawang, Jelebu, a weekly dhikr ceremony is held every Thursday night and Friday after Maghrib prayers. Meanwhile, the TQWN dhikr ceremony at Surau Kampung Kondok, Nilai is held every Sunday night Monday starting after Maghrib until 10.30 pm. For TSD at Pondok ar-Raudhah Kuala Jempol, a dhikr ceremony is held every Thursday night, Friday starting after Maghrib until 9.30 pm. Finally, the TDM dhikr ceremony in Seremban 2, dhikr ceremony is held every Saturday night Sunday from 9.30 pm to 11.20 pm. 
Figure 2: The Practice of Dhikr in Tarekat Tasawuf in Negeri Sembilan

Weekly Zikr Ceremony in Tarekat Tasawuf Practice Centres in Negeri Sembilan

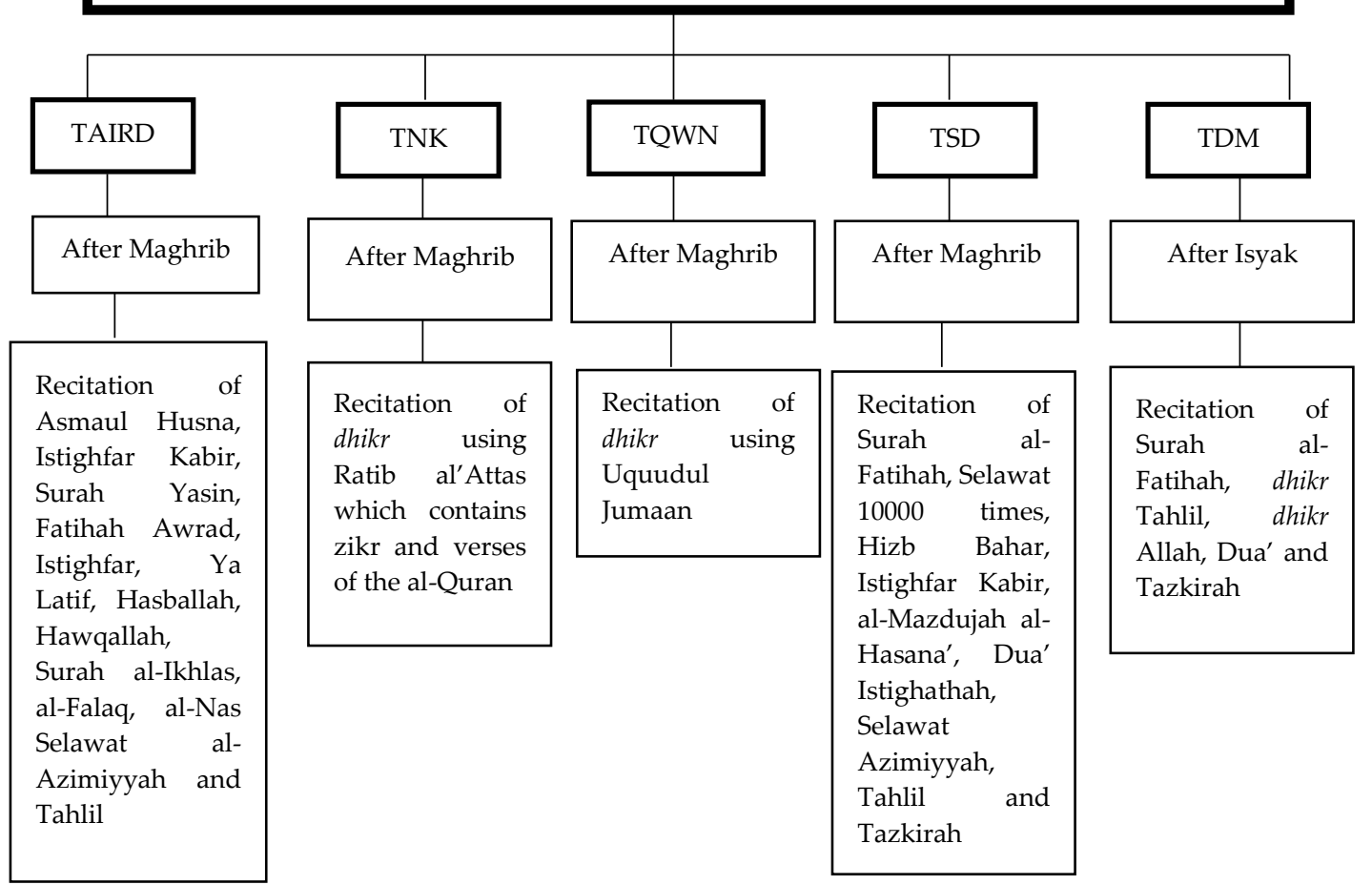

(Source: Researcher Analysis, 2020)

\section{The Impact of Implementing Dhikr Activities Toward Spiritual Practice Amongst the Community in Negeri Sembilan}

The implementation of $d h i k r$ ceremonies in every practice centre of tarekat tasawuf is indirectly seen to had an impact on the spiritual practice amongst the community in Negeri Sembilan. The impacts that have been identified are as follows:

\section{Socialising Tarekat Tasawuf}

The impact of life influenced by the secularisation and modernisation of Western civilisation has caused modern society today to suffer from various mental problems and psychiatric disorders. The development of western civilisation that neglects the spiritual aspect of human beings has also failed in the Muslim community development agenda (Abd Razak, Sa'ari, \& Rahman, 2018). Therefore, through the practice of Sufism as a spiritual path derived from the Qur'an and Sunnah, it has been proven to be effective in bringing individuals to obtain happiness and peace of mind.

Therefore, the step to socialise the Sufi order today is important because the practice of the Sufi order can form a believer to be the best servant of God. Attending the Sufi order also aims at balancing between physical and spiritual development in human life to become a person who can achieve and appreciate the value of compassion in life (Sidek, 2017).

Among the efforts towards socialising the Sufi order can be seen through the organisation of regular remembrance of the Sufi order held at the practice centres of the Sufi order throughout Negeri Sembilan. The dhikr ceremony serves as a platform for tarekat practitioners and the surrounding community to improve themselves through spiritual training. The sheikh of the Sufi order plays a significant role in disseminating knowledge related to remembrance to the community by providing knowledge about the practice of remembrance of the Sufi order based on the Quran and Sunnah. When 
the community supported the dhikr tarekat tasawuf, the community can act as a promotional agent to others to get to know more about the concept of tarekat tasawuf and, in turn, will develop further the growth of tarekat tasawuf in Negeri Sembilan.

In addition, the presence of dhikr ceremonies of tarekat tasawuf in each district provides space for the local community to choose to participate in any dhikr ceremonies conducted. This is done at the AlSyazuliyah Al-Darqawiyah (TSD) practice centre, Bahau, which opens up space and opportunities for the local community to participate in dhikr ceremony (Nasir Othman, 2018). The TSD remembrance ceremony is not only for the practitioners of the tarekat but also invites the local community to participate. This is also done by other tarekat practice centres such as TAIRD, TQN, and TNK. For TAIRD, TSD, and TQN, the sheikhs of the tarekat open space for the community with dhikr at their respective practice centres. Meanwhile, for TNK, the sheikh of the tarekat allocated a special dhikr ceremony at the Masjid Jamek Kuala Klawang, Jelebu, to provide an opportunity for the local community to recite dhikr together (Muhammad Firdaus, Personal Communication, April 1, 2018).

This also proves that the sheikh of the sect does not exclude the remembrance ceremony but uses an inclusive approach which opens space for the community to participate in the remembrance ceremony. This process aims to reveal to the public the forms of the practice of dhikr in the tarekat tasawuf so that the community increases the knowledge about the practice of dhikr tarekat and subsequently can purify the opposing views on the tarekat tasawuf. Undoubtedly, some practices need to be excluded. However, it is time for the sheikh of the tarekat to take steps to include some of the practices of dhikr tarekat to ensure that this harmful problem can be purified.

\section{The Involvement of Sufi Practitioners in the Sufi Economic Model to Improve Economic Status}

Every individual has a sense of love for property. To draw closer to God, an individual will usually divert his attention and obsession with worldly possessions and turn to the path of loving God. They will change from a person who lusts for worldly possessions to a simple life, accompanied by the nature of qanaah (contentment), and eventually lead to a sense of trust by making Allah his only protector, guardian, and savior. Those who have a proper understanding of God will reject all desires for things of material nature. They do not worry about the sustenance obtained by sustenance that can be achieved by practicing a combination of work and spiritual deeds or only through spiritual deeds (Noyo Sarkun \& Al-Kindely, 2013).

This can be seen through the involvement of Sufi practitioners in Negeri Sembilan in the Sufi economy. The practice of Sufi economics displays the elements of Sufism as the main element in influencing the patterns and behaviors of tarekat practitioners in seeking and using property in support of the economic model. The existing practice by the practitioners of the Sufi order in Negeri Sembilan, when a remembrance ceremony is held, they will gather at the practice centre of their respective orders. Indeed, the success of a remembrance ceremony will be tied to financial commitment and expenses. Thus, some individuals from among the tarekat practitioners themselves will contribute financially and materially based on their responsibility and concern.

In this case, the practitioners of Sufism in Negeri Sembilan strongly support the concept of helping based on piety. They hold that the business of earning a living is individual, and it is only temporary. Therefore, it is a very demanding thing for them to help their members who are in need and together make the remembrance ceremony a success (Nasir Othman, Personal Communication, April 5, 2018). This is also proof that the practitioners of the tarekat have practiced the concept of almsgiving as stated in the Qur' an surah al-Baqarah verse 261 and coupled with the blessings of the remembrance ceremony that can lead to an increase in their sustenance (Muhammad Firdaus, Personal Communication, April 1, 2018).

\section{Tarekat Practice Centre as a "Psychiatric Hospital"}

The institution of Sufism is considered as a location that serves as a "Psychiatric Hospital" (Muhammad Firdaus, Personal Communication, April 1, 2018). This coincides with the principles in the tarekat itself, which lead to the practice of cleanliness (tazkiyah) and spiritual purity (tasfiyah), 
namely the nature of taqwa, dhikrullah (remembrance of God), and muraqabah (the practice of meditation), as well as the practice of suluk (road) or khalwat (solitude) all of which to be close to God. All of these topics are more focused on the positive internal and spiritual aspects through the leadership of the sheikh. If the physical illness can be treated by its specialist, the medical doctor, then the spiritual illness can also be treated by its expert, the sheikh of the sect. This shows the importance of the role and position of a sheikh of the sect in caring for the spiritual and personality of the sect practitioners to obtain precise spiritual stability (Wan Sayed, Shuhari, \& Wan Jusoh, 2020).

In addition, the systematic practice of dhikr tarekat tasawuf has provided an opportunity for the local community to participate in the practice of $d h i k r$ more systematically. For example, the community has the opportunity to recite $d h i k r$ in large numbers. Undoubtedly, remembrance with a large number can be performed individually, but it will give a more enthusiastic feeling if done in groups. This can be seen in the practice of the TSD dhikr ceremony at Pondok Raudah Jempol led by Ustaz Nasir Othman as the TSD sheikh, which opens up opportunities for the local community to recite dhikr together. The practice sets the rate of the number of dhikr that needs to be recited, which is 10 thousand times Salawat. Thus, the participants in the remembrance ceremony have the opportunity to pray 10 thousand times at each remembrance ceremony conducted according to the method that has been set (Nasir Othman, Personal Communication, April 5, 2018). This matter has indirectly given a new improvement at the individual level in the practice of dhikr worship, which was not as frequent as the current frequency through activities in the dhikr ceremony of the Sufi order.

The dhikr activity can also be practiced individually at home without engaging in tarekat dhikr ceremonies. However, if this space can contribute to a more structured and systematic way and set of methods and the guidance of the sheikh of the sect, then this excellence practice is more demanded.

\section{Majlis Dhikr Tarekat as One of The Methods to Resolve Drug Addiction among The Community of Negeri Sembilan}

The practice of regular and systematic dhikr helps the recovery of former drug addicts in overcoming their addiction. It also helps former addicts to become closer to Allah by practicing dhikr, and their lives will be better because the addiction can be controlled. The practice of dhikr can help former addicts change their behaviour and help them become pious servants of God. Although it is not easy to overcome one's addictive impulse with a strong desire and impulse can change everything by the will of Allah SWT (Sabri, Sulaiman, \& Sarnon, 2018).

The TQWN remembrance ceremony of the Sufi order, lead by Ustaz Shaifudin Maulup has helped drug addicts in recovering their addiction to drugs (Shaifudin Maulup, Personal Communication, January 7, 2018). The rehabilitation treatment for drug addicts performed by Ustaz Maulup was first introduced in Indonesia by Kyai Haji Ahmad Sahib al-Wafa 'Taj al-Ariffin and is better known as Abah Anom. He is the Suryalaya boarding school founder in Tasikmalaya, West Java, Indonesia, who is also a murshid, the spiritual guide, of the famous Qadiriyyah wa Naqshabandiyyah sect in Java. Using this method, Ustaz Maulup helps drug addicts in Negeri Sembilan by employing dhikr performed at the TQWN practice centre in Labu Negeri Sembilan. This is also practiced at the Surau Kampung Kondok, Labu, when it is used as a place for dhikr ceremonies for followers of the tarekat and the local community apart from being attended by tarekat practitioners from among drug addicts. In this context, they recite dhikr together in the dhikr ceremony lead by the sheikh of the sect.

\section{Individual Spiritual Development through Dhikr Ceremony}

The practice of worship is an effort to purify the soul and nurture a sense of faith in the human heart. Indeed, it is a good deed that will give its share to each perpetrator as long as the practice of worship is still bound by Islamic law that coincides with the Quran, Sunnah, and the consensus of Muslim scholars. However, an extraordinary spiritual life always fills the existing void with a variety of acts of worship. Such a practice shows a continuity of the diversity of worship in creating a sense of servitude in the perpetrator. This shows that the field of spiritual practice is vast and has its variations 
so that it becomes a practice that is very close to the human self. Apart from that, it is also to open space for the community to increase the types of worship appropriate to their circumstances and abilities.

Looking at the discussion related to spiritual development between modern psychology and the Sufi order has many differences. Human spiritual development through modern psychology is humancentred, whereas, in the discipline of Sufism, it is God-focused. In other words, modern psychology emphasises human development for human beings like the streams of Humanism and Existentialism, and the scope of human development and development revolves around worldly life only. Whereas Sufism attaches importance to human development for God. So the scope of human life is broader, which includes life in this world and the hereafter (Mokhtar, 2016).

This can be seen in the context of the dhikr ceremonies of Sufism, especially in Negeri Sembilan. The practice of this dhikr ceremony provides space for tarekat practitioners and the surrounding community in varying their worship practices and spiritual practices. Indirectly, the continuity of the diversity of worship done individually and in a congregation can enhance faith in human beings.

\section{Practical Periodic Remembrance Ceremony Creating a Relationship between human beings and God}

Looking at the discussion of modern psychology places minimal emphasis on the divine aspect, whereas the approach of Sufism sometimes ignores worldly life and the realities of current society because it focuses on the divine aspect more than anything else. The approach of modern psychology is said to be too materialistic and worldly, while the approach of Sufism is too spiritual and centred on divinity alone, so the approach to the spiritual development of the perfect human should combine the two approaches. The combination of these two approaches balances the needs of the human body and spirit that is through the development of the human body in a scientific method in addition to the parallel of religious elements that refer to aspects of Sufism, to finally create a process of spiritual development in perfect human life (Mokhtar, 2016).

To achieve this stage, implementing the dhikr ceremony of this Sufi order, can create a relationship between a group of people in one aspect and with Allah SWT through the practice of dhikr en masse. Through the practice of the dhikr ceremony of the Sufi order led by the sheikh of the order, is a practice that leads to peace of mind to achieve the enlightenment of God. If this goal can be achieved through direct internal practice, then it is one of the indicators that the individual is guaranteed to get happiness in this world and the hereafter.

The data presented in this article shows the positive outcomes of the tarekat tasawuf ceremony of $d h i k r$ that invites the community to participate. Following the pathway of spirituality suggested by Hodge (2000), this practice can create a psychodynamic of ritual and social support. By participating in this activity, people in the community gain social support by connecting with one another and with God. Besides, this faith community through $d h i k r$ can help people with their problems such as anxiety, loneliness, security, isolation, and many others. Tarekat tasawuf dhikr ceremony served in protective and curative meaning to the wellbeing of the community.

\section{Conclusions}

In conclusion, the results of the study found that the dhikr ceremony of the Sufi order at the Negeri Sembilan Sufi practice centre had an impact on the spiritual practice of the Negeri Sembilan community. The existence of this remembrance ceremony is an additional platform for the community who want a systematic spiritual practice with the sole intention of getting closer to Allah SWT. This practice of dhikr which is believed to bring one closer to Allah can lead to a change in behaviour to be a pious servant of Allah SWT. In addition, regular dhikr ceremonies held at tarekat practice centres throughout Negeri Sembilan can create a positive atmosphere that the community always remembers and mentions Allah without being limited by time and place. Through this approach as well, giving birth to a society that has spiritual strength and their soul is full of remembrance of Allah SWT. Not only that, but the dhikr ceremony of tarekat tasawuf also serves as one of the methods to solve drug addiction among the people of Negeri Sembilan. Based on the approach of Sufism, the individuals involved in this drug problem are those who lack spiritual strength or those whose souls are empty. 
Through the dhikr ceremony of tarekat tasawuf proved to be a process of intervention given to individuals involved with drug problems. Finally, this remembrance ceremony can create a society that is always on the axis and galaxy of spirituality that is strong in enhancing piety to God towards achieving the status of Baldatun Tayyibatun wa Rabbun Ghafur (prosperity of the nation).

\section{References}

Abd Razak, S., Sa'ari, C. Z., \& Rahman, S. M. H. S. A. (2018). Relevansi Tasawuf dan Pembangunan Rohani Insan: Satu Sorotan Awal. BITARA International Journal of Civilizational Studies and Human Sciences, 1(4), 71-84.

Abdullah, A. R. (1997). Pemikiran Islam di Malaysia. Jakarta: Gema Insani Press.

Al-Asqalani, I. H. (2001). Fath al-Bari Fi Syarh Sahih al-Bukhari. Kaherah: Maktabah Misr.

Al-Attas, S. M. N. (1963). Some Aspects of Sufism as Understood and Practised Among the Malays. Singapore: Malaysia Sociological Research Institute.

Al-Sakandari, I. 'Ata' A. (1961). Miftah al-Falah wa Misbah al-Arwah. Kaherah: Maktabah wa Matba'ah Mustafa alBabi al-Halabi wa Awladih.

Al-Șan'ani, M. I. I. (2006). Subl al-Salam Sharh Bulugh al-Maram. Riyaḍ: Maktabah al-Ma'ārif li Nashr al-Tawzi'.

Awang, I. (2001). Kaedah Penyelidikan: Suatu Sorotan. Kuala Lumpur: Intel Multimedia and Publication.

Fahmi, A. H. M., \& Ishak, S. (2017). Impact of Integrated Management on the Development of Tarekat Tasawuf in Negeri Sembilan, Malaysia. Jurnal Intelek, 12(2), 1-10.

Hassan, H. (1990). Tarekat Ahmadiyah di Malaysia. Kuala Lumpur: Dewan Bahasa dan Pustaka.

Hodge, D. R. (2000). Spirituality: Towards a theoretical framework. Social Thought, 19(4), 1-20. https://doi.org/10.1080/15426432.2000.9960271

Ibrāhim, S. (1996). Maliziya wa Atharuha 'ala al-Da'wah al-Islamiyyah wa al-Mujtama' al-Islami. Universiti Al-Azhar.

Kamal, M. H. M. (2017). Memelihara Kemurnian Akidah dan Amalan Muslim: Peranan dan Cabaran Institusi Mufti dalam Era Globalisasi. Jurnal KANUN, 29(2), 36-57.

Lebar, O. (2009). Penyelidikan Kualitatif Pengenalan Kepada Teori dan Metod. Perak: UPSI.

Manzur, I. (2013). Lisan al-'Arab. Kaherah: Dar al-Hadith.

Marican, S. (2005). Kaedah Penyelidikan Sains Sosial. Selangor: Pearson Malaysia Sdn. Bhd.

Meerangani, K. A. (2019). Peranan Ulama Dalam Penyebaran Ajaran Islam di Pulau Besar, Melaka (The Role of Muslim Scholars in Spreading the Teaching of Islam in Pulau Besar, Melaka). Journal of Al-Tamaddun, 14(2), 65-74. https://doi.org/10.22452/JAT.vol14no2.6

Mokhtar, M. K. (2016). Pembangunan Rohani Menurut Perspektif Tasawuf dan Psikologi Moden. Bangi: Penerbit Universiti Kebangsaan Malaysia.

Noyo Sarkun, M. R., \& Al-Kindely, S. K. H. (2013). Model Ekonomi Sufi Imam Al-Ghazali. Jurnal Teknologi, 64(1), 111-120. https://doi.org/10.11113/jt.v64.1313

Piaw, C. Y. (2012). Asas Statistik Penyelidikan. Kuala Lumpur: Mc Graw Hill Education.

Sabri, N. M., Sulaiman, W. S. W., \& Sarnon, N. (2018). Penerokaan Amalan Dhikr Dan Perubahan Tingkah Laku Dalam Proses Kepulihan Penagihan Dalam Kalangan Penagih Bebas Dadah. Journal of Sciences and Humanities, 13(2), 141-153.

Salleh, N., Badaruddin, F., Rasit, R., Kamarzaman, M. H., Ismail, I., \& Mohd. Nor, A. Y. (2020). The Importance of Tasawuf Practice in the Life of Modern Society. International Journal of Business and Social Science, 11(10), 8389. https://doi.org/10.30845/ijbss.v11n10p7

Sang, M. S. (2009). Literatur dan Kaedah Penyelidikan. Selangor: Penerbitan Multimedia Sdn Bhd.

Sidek, J. (2017). Strategi Memasyarakatkan Tarekat. Jurnal Qalbu, 3(1), 89-111.

Wan Sayed, W. S., Shuhari, M. H., \& Wan Jusoh, W. H. (2020). Institusi tarekat tasawuf dalam pemantapan spiritual insan. Malaysian Journal Of Islamic Studies (MJIS), 4(2), 55-66. https://doi.org/10.37231/mjis.2020.4.2.144

Wizarah al-Awqaf wa al-Shu'un al-Islamiyyah. (1992). al-Mawsu'ah al-Fighiyyah. Kuwait: Wizarah al-Awqaf.

Zahri, M. (1984). Kunci Memahami Ilmu Tasawuf. Surabaya: Pustaka Bina Ilmu.

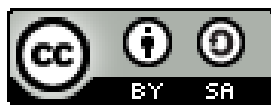

(C) 2021 by the authors. Submitted for possible open access publication under the terms and conditions of the Creative Commons Attribution (CC BY SA) license (https://creativecommons.org/licenses/by-sa/3.0/). 